\title{
Religious Freedom, US Law and Liberal Political Theory
}

In this wonderful book, Nelson Tebbe brings principled coherence to legal controversies pitting religious freedom against LGBT rights. Arguing against sceptics who deny that conflicts about religious liberty can be solved by appeal to reason, he boldly seeks to identify a reasoned common ground of substantive agreement. One cannot fail to admire the wideranging yet thoughtful way in which he deploys his argument, even though one may doubt whether critics will agree that the deployment of reason—even of the coherentist kind that Tebbe defends_-generates only one set of reasonable principles.

Tebbe’s reason is recognizably liberal and egalitarian. The basic move animating his book is that claims to religious freedom are circumscribed by the rightful demands of the egalitarian age. When LGBT rights conflict with religious freedom, they-most of the timeshould take precedence. Of course, Tebbe is no militant secularist and, as a scholar of religious freedom, he seeks to give religious freedom its due. What is striking about Religious Freedom in an Egalitarian Age, however, is the extent to which its approach to religious freedom is suffused by a broadly liberal egalitarian political philosophy. Roughly, this political philosophy starts from the assumption that freedom of religion-like other freedoms — should be protected from persecution or animus, but should not generally enjoy special support or accommodation from laws that incidentally burdens its exercise. Special accommodation is only warranted if one of the following basic liberal principles can be invoked (this is my terminology, not Tebbe's, but it closely follows his):

- The Harm Principle: Citizens can act on their religious beliefs as long as they do not harm others — or generate undue hardship or illegitimate costs for them. 
- The Association Principle: Religious associations can choose their members or employees on otherwise illegitimate grounds (such as gender or sexuality) only if they operate on private, intimate, and/or noncommercial grounds.

- The Equal Standing Principle: Religious groups can be supported or funded by the state only if this is compatible with equal civic standing and does not signify state endorsement of controversial comprehensive doctrines.

Tebbe's liberal political theory assumes that religious freedom is not a special, primary, or foundational freedom. Like other basic liberal freedoms, its exercise is constrained by the rules of social cooperation and compatibility with the rightful claims of others-here, in particular, LGBT claims to equality.

This political theory is one I embrace wholeheartedly. I also agree with most of the specific proposals that Tebbe puts forward and admire his learned effort to give coherence to a notoriously intricate body of law, that of recent US religion clauses jurisprudence. There is a tension, however, between Tebbe’s political philosophy and his commitment to legal coherentism. In brief, it is this. The three principles set out above do not make reference to religious freedom as such. They are broad interpretive principles that give guidance in controversies about religion in the state, but that do not apply specifically or exclusively to religion. The Harm principle can plausibly be said to apply to all moral, or at least conscientious, commitments. The Association principle likewise applies to all associations, and singles out, not the content of their commitments but, rather, their mode of association. The Equal Standing principle applies to all divisive or comprehensive social identities. In no case does the fact that demands are specifically religious do any independent normative work. If religion can be analytically disaggregated into conscience, association, identityinter alia — is it still useful as an integrated legal category? The problem for Tebbe-and other US liberal legal constitutionalists-is that the constitutional system they seek to give 
“coherence” to recognizes religious freedom as a special freedom; and yet their political theory is one that implicitly denies such status.

Tebbe has reflected on related questions in a pioneering article entitled "NonBelievers” (Virginia Law Review 97 [2011]: 1111, 1156-57), in which he addressed one of the central puzzles of the discipline of religious studies — the indeterminacy of the concept of religion — and its problematic connection to a central feature of US constitutional law: the special status of religion in the First Amendment. On the polyvalent approach he defended there, the religion clauses protect the rights of nonbelievers, but these are unavoidably polyvalent rights, because they attach to an array of normatively relevant features of nonbelief. What, however, if exactly the same could be said about religion itself? This tantalizing possibility was muted—but not fully explored—in Tebbe's earlier article. If the rights of religion can be adequately protected via a polyvalent approach that disaggregates them into rights of conscience, association, and citizenship, does this approach still "cohere” with the US constitution? Is there not a tension between Tebbe's political theory and his legal approach? The deeper question raised by Tebbe’s pioneering book is whether we need the concept of religious freedom at all in an egalitarian age, or whether the values that religious freedom has historically guaranteed can be adequately protected via a more secular constitution.

Cécile Laborde

University of Oxford Author of Liberalism's Religion 